\title{
Patient satisfaction with primary health care services in two districts in Lower and Upper Egypt
}

\author{
M. Gadallah, ${ }^{1}$ B. Zaki, ${ }^{2}$ M. Rady, W. Anwer and I. Sallam ${ }^{2}$
}

$$
\begin{aligned}
& \text { رضى المريض بكلمات الرعاية المحهية الأولية في مقاطعة شمالية وأنحرى بمنوبية في مصر }
\end{aligned}
$$

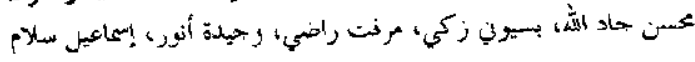

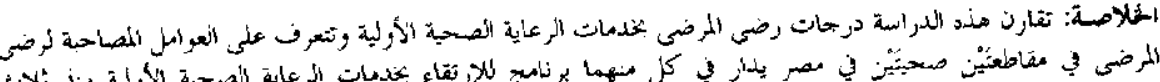

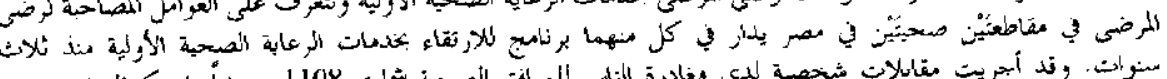

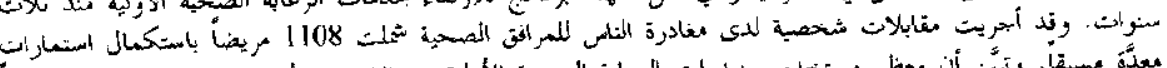

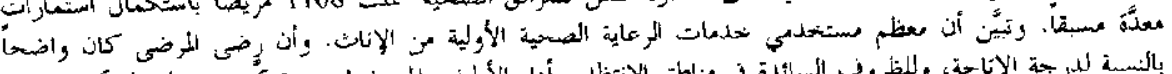

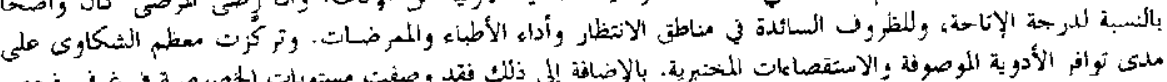

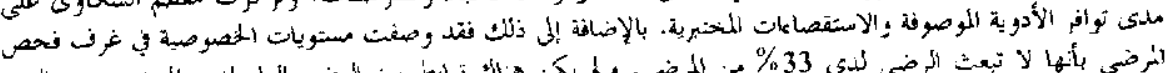

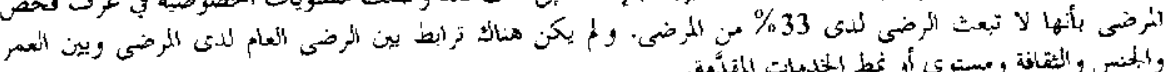

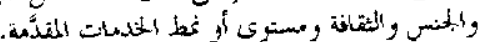

ABSTRACT This study compares patient satisfaction with primary health care services and identifies factors associated with patient satisfaction in two health districts in Egypt where a project for upgrading primany health care services had been running for three years. An exil interview was conducled for 1108 patients using a structured questionnaire. The results revealed that most clients using primary health care services were females. Patient satisfaction was high for accessibility, waiting area conditions and performance of doctors and nurses. The main complaints centred on the availability of prescribed dnugs and laboratory investigations. Additionally, level of privacy in the consultation room was described as unsatisfactory by $33 \%$ of patients. There was no association between overall patient satisfaction and age, gender, education ievel or type of service received.

Satisfaction des patients concernant les services de soins de santé primaires dans deux circonscriptions de Basse et Haute Egypte

RESUME La présente étude compare la satisfaction des patients concernant les services de soins de santé primaires et identifie les facteurs associés a la satisfacion des palients dans deux circonscriptions sanitaires en Egypte oú un projet d'amélioration des services de soins de santé primaires etait en place depuis trois ans. En utilisant un questionnaire structuré, 1108 patients ont été interrogés à la sortie. Les résultats ont rẻvèlè que la plupart des clients qui utilisaient les services de soins de santé primaires étaient des femmes. La satisfaction des patients était élevée pour ce qui concerne laccessibilité, les conditions dans la salle d'attente et la prestation des médecins et des infirmières. Les plaintes principales concernaient la disponibilité des médicaments prescrits et les examens de laboratoire. En outre, le niveau d'intimité dans la salle de consultation était décrit comme insatisfaisant par $33 \%$ des patients. II r'y avait pas d'association entre la satisfaction générale des patients et l'àge, le sexe, le niveau d'instruction ou lo type de service reçu.

"Faculty of Medicine, Ain Shams University, Cajro, Egypt

Ministry of Health and Population. Cairo, Egypt.

Received: 17/07/02; accepted: 24/10102

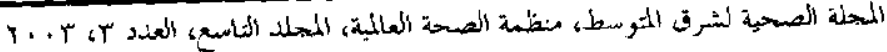




\section{Introduction}

Customer satisfaction is an important measure of service quality in health care organizations. From a management perspective, patient satisfaction with health care is important for several reasons. First, satisfied patients are more likely to maintain a consistent relationship with a specific provider. Second, by identifying sources of patient dissatisfaction, an organization can address system weaknesses, thus improving its risk management $[l]$. Third, satisfied patients are more likely to follow specific medical regimens and treatment plans. Finally, patient satisfaction measurement adds important information on system performance, thus contributing to the organization's total quality management. Health service quality has three dimensions: client quality, professional quality and management quality [2]. Client quality is the dimension that receives most attention in discussions of quality of health care based on how satisfied clients are with their care.

In Egypt, the health care infrastructure is reasonable in terms of facilities and personnel. The real challenge is to improve staff performance and patient satisfaction in order to minimize rework, wastage, delay and costs.

Today, we recognize that quality as perceived by the health care recipient is vitally important. As a result of this new focus, measurement of customer satisfaction has become equally important $[3,4]$.

The aim of this study is to compare patient satisfaction with primary health care services in Lower and Upper Egypt. We explored the negative and positive aspects as perceived by patients. The results can be used to improve the performance of the primary health care system.

\section{Methods}

\section{Sites of the study}

Two governorates were selected randomly from 6 governorates in which a project to upgrade primary health care services had been implemented for 3 years (19982001). One governorate (Sharqiya) was selected from 4 governorates (Minufiya, Kafr El Sheikh, Sharqiya, and Beheira to represent Lower Egypt and another (Minya) was selected from 2 governorates (Minya and Sohag) to represent Upper Egypt.

Ten primary health care units/centres were selected randomly from Belbis district in Sharqiya governorate. Another 10 primary health care units/centres were selected in a similar way from Abu Korkas district in Minya governorate.

\section{Sample}

According to the sample size calculation, a sample of 514 patients for each site was required. Allowing for incomplete or unreliable answers, an extra $10 \%$ of the sample size was added. The final sample eligible for analysis was 554 patients for each study area. The following criteria were used for sample size calculation: confidence interval $95 \%$; power of the test $80 \%$; expected satisfaction rate $93 \%$ in Belbis district and $97 \%$ in Abu Korkas district.

\section{Tools}

This was a cross-sectional study followed by comparison between the study sites. An exit interview questionnaire was administered to patients in the selected primary health care facilities. The questionnaire was tested on 50 patients attending the primary heath care facilities in each study site in order to identify any unclear or improper questions and to estimate the overall satisfaction rate. Minor changes were made,

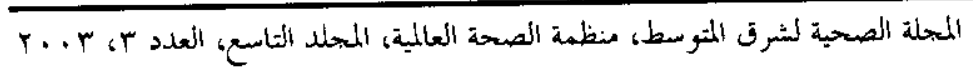


and the final form of the questionnaire was approved by the investigators and some key personnel from the Ministry of Health and Population.

The survey was administered by a specially trained female social worker working in the same facility. The study investigators visited each site to train the interviewers, explain the objectives of the study and stress the importance of obtaining exact answers. The investigators then observed several demonstration exit interviews in order to gauge the capabilities of each interviewer.

The questionnaire collected sociodemographic characteristics and rated each patient's satisfaction level with regard to accessibility of primary health care facilities, waiting area conditions, clinical examination and drug prescription.

Patients had the option of answering as satisfied, not satisfied or neutral, but very few survey subjects described themselves as neutral on any of the questions; and the overwhelming majority (99\%) answered either satisfied or not satisfied. Therefore, the investigators decided to consider answers of neutral as not satisfied.

\section{Statistical analysis}

The questionnaire was recoded to suit the computer statistical package SPSS, version 9.0. Mean, median, standard deviation and frequency distribution were calculated. Both chi-squared test for qualitative data and the Mann-Whitney $U$ test for quantitative non-parametric data were done. The level of significance was set at 0.05 .

\section{Results}

The majority of clients were between 20 and 60 years old with only a slight difference between the two districts regarding age distribution (Table 1). Women made up $70.6 \%$ and $61.4 \%$ of survey recipients in Belbis and Abu Korkas respectively. In terms of educational status, there was a significant difference between the districts $(P<0.001)$, with $57.7 \%$ illiteracy among survey recipients in Abu Korkas compared to $35.9 \%$ in Belbis. There was also a significant difference between the two districts in terms of the type of health care services being received. Whereas in Belbis, $63.2 \%$ were outpatient clients and $20.4 \%$ were clients seeking antenatal care, in Abu Korkas the corresponding figures were $77.1 \%$ and $6.3 \%$ respectively; results for all types of services are given in Table 2.

Table 2 shows that primary health care facilities were described as easily accessible by $83.0 \%$ of Belbis respondents and $91.9 \%$ in Abu Korkas. There was no signi-

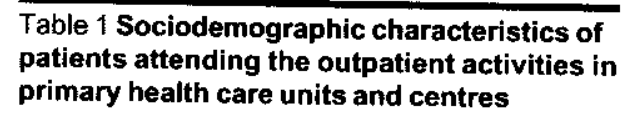
patients attending the outpatient activities in primary health care units and centres

\begin{tabular}{lrrrr}
\hline Variable & \multicolumn{2}{c}{$\begin{array}{c}\text { Belbis } \\
(n=554)\end{array}$} & \multicolumn{2}{c}{$\begin{array}{c}\text { Abu Korkas } \\
(n=554)\end{array}$} \\
& No. & $\%$ & No. & $\%$ \\
\hline Age (years) & & & & \\
$<20$ & 171 & 30.9 & 173 & 31.2 \\
$21-60$ & 351 & 63.4 & 355 & 64.1 \\
$>60$ & 32 & 5.8 & 26 & 4.7 \\
Sex** & & & & \\
Male & 163 & 29.4 & 214 & 38.6 \\
Female & 391 & 70.6 & 340 & 61.4 \\
Education $n^{* * *}$ & & & & \\
Hliterate & 199 & 35.9 & 320 & 57.7 \\
Read and write & 75 & 13.5 & 83 & 15.0 \\
Primary/secondary & 242 & 43.7 & 124 & 22.4 \\
University & 38 & 6.9 & 27 & 4.9 \\
\hline
\end{tabular}

${ }^{\star \star}$ Significant at $P<0.01$.

***Significant at $P<0.001$.

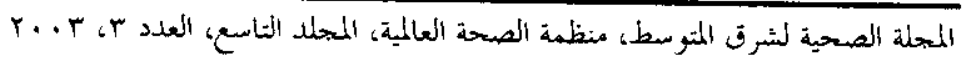


Table 2 Patient satisfaction regarding the accessibility of health services

\begin{tabular}{|c|c|c|c|c|}
\hline \multirow[t]{2}{*}{ Variable } & \multicolumn{2}{|c|}{$\begin{array}{c}\text { Belbis } \\
(n=554)\end{array}$} & \multicolumn{2}{|c|}{$\begin{array}{c}\text { Abu Korkas } \\
\qquad(n=554)\end{array}$} \\
\hline & No. & $\%$ & No & $\%$ \\
\hline \multicolumn{5}{|l|}{ Type of service ${ }^{* * *}$} \\
\hline Outpatient & 350 & 63.2 & 427 & 77.1 \\
\hline Child vaccination & 41 & 7.4 & 49 & 8.8 \\
\hline Antenatal care & 113 & 20.4 & 35 & 6.3 \\
\hline Family planning & 44 & 7.9 & 15 & 2.7 \\
\hline Emergency & 6 & 1.1 & 28 & 5.1 \\
\hline \multicolumn{5}{|c|}{$\begin{array}{l}\text { Accessibility of primary } \\
\text { health care facility }{ }^{\star *}\end{array}$} \\
\hline Easy & 460 & 83.0 & 509 & 91.9 \\
\hline Difficult & 94 & 17.0 & 45 & 8.1 \\
\hline \multicolumn{5}{|l|}{ Method of arrival } \\
\hline Walking & 414 & 74.7 & 428 & 77.3 \\
\hline By car/motorcycle & 126 & 22.7 & 117 & 21.1 \\
\hline Animal & 14 & 2.5 & 9 & 1.6 \\
\hline \multicolumn{5}{|c|}{ 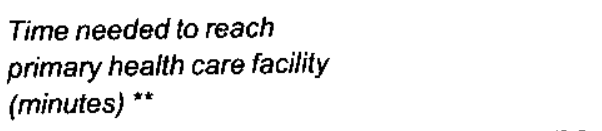 } \\
\hline$<10$ & 225 & 40.6 & 319 & 57.6 \\
\hline $11-15$ & 160 & 28.9 & 80 & 14.4 \\
\hline$>15$ & 169 & 30.5 & 155 & 28.0 \\
\hline \multicolumn{5}{|l|}{ Cost of service ${ }^{* \star}$} \\
\hline Reasonable & 515 & 93.0 & 541 & 97.7 \\
\hline Unreasonable & 39 & 7.0 & 13 & 2.3 \\
\hline
\end{tabular}

**Significant at $\mathrm{P}<0.01$.

${ }^{* * *}$ Significant at $\mathrm{P}<0.001$

ficant difference between the two districts regarding the patients' methods of reaching the primary health care facility $(P>0.05)$. In terms of the amount of time needed to reach primary health care facilities, $40.6 \%$ of Belbis respondents said they were less than 10 minutes away and $28.9 \%$ said it took between 11 and 15 minutes, while in
Abu Korkas the corresponding figures were $57.6 \%$ and $14.4 \%$. In Belbis, $7 \%$ of the clients stated that the cost of the service was unreasonable compared to $2.3 \%$ in Abu Korkas $(P<0.01)$.

Patient satisfaction with the facilities in the waiting areas is shown in Table 3.

Regarding patient satisfaction with examination rooms and clinical consultations (Table 4), $99.6 \%$ of respondents in Belbis said they were satisfied with the performance of the nurses compared with $96.8 \%$ in Abu Korkas $(P<0.01)$. There was no significant difference $(P>0.05)$ between the two districts regarding whether patients felt the doctor had listened attentively to their complaints. In Belbis $16.2 \%$ of clients stated that there was more than one patient inside the examination room, while in $\mathrm{Abu}$ Korkas the figure was $50.7 \%(P<0.001)$. In both districts, more than $97 \%$ of clients said they felt they had been examined

Table 3 Patient satisfaction with waiting area

\begin{tabular}{|c|c|c|c|c|}
\hline \multirow[t]{2}{*}{ Variable } & \multicolumn{2}{|c|}{$\begin{array}{c}\text { Belbis } \\
(n=554)\end{array}$} & \multicolumn{2}{|c|}{$\begin{array}{c}\text { Abu Korkas } \\
(n=554)\end{array}$} \\
\hline & No. & $\%$ & No & $\%$ \\
\hline \multicolumn{5}{|l|}{ Availablity of seats ${ }^{\star \star}$} \\
\hline Enough & 493 & 89.0 & 466 & 84.1 \\
\hline Not enough & 61 & 11.0 & 88 & 15.9 \\
\hline \multicolumn{5}{|l|}{ Comfort of seats } \\
\hline Comfortable & 484 & 87.4 & 467 & 84.3 \\
\hline Not comfortable & 70 & 12.6 & 87 & 15.7 \\
\hline \multicolumn{5}{|l|}{ Ventilation $^{*}$} \\
\hline Satisfactory & 522 & 94.2 & 541 & 97.7 \\
\hline Not satisfactory & 32 & 5.8 & 13 & 2.3 \\
\hline \multicolumn{5}{|l|}{ Cleanliness $^{\star \star}$} \\
\hline Clean & 529 & 95.5 & 547 & 98.7 \\
\hline Dirty & 25 & 4.5 & 7 & 1.3 \\
\hline
\end{tabular}

*Significant at $\mathrm{P}<0.05 ;{ }^{*}$ Significant at $\mathrm{P}<0.01$.

المجلة الصحية لشرق المتر سط، منظمة الصحة العالمية، المحلد التاسع، العلد ب، ب. . ب 
Table 4 Patient satisfaction regarding examination room and clinical consultation

\begin{tabular}{lcc}
\hline Variable & Belbis & Abu Korkas \\
& $(n=554)$ & $(n=554)$ \\
& No. $\%$ & No $\%$ \\
\hline
\end{tabular}

Patient-nurse relationship ${ }^{\star *}$

$\begin{array}{lrrrr}\text { Proper } & 552 & 99.6 & 536 & 35.8 \\ \text { Improper } & 2 & 0.4 & 18 & 3.2\end{array}$

Listening and discussion

about the patient's complaint

$\begin{array}{lrrrr}\text { Proper } & 534 & 96.4 & 540 & 97.5 \\ \text { Improper } & 20 & 3.6 & 14 & 2.5\end{array}$

More than one patient

inside the examination room ${ }^{* * *}$

$\begin{array}{lrrrr}\text { Yes } & 90 & 16.2 & 281 & .0 .7 \\ \text { No } & 464 & 83.7 & 273 & 4.3\end{array}$

Patient examination by doctor

$\begin{array}{lrrrr}\text { Proper } & 544 & 98.2 & 541 & 97.7 \\ \text { Improper } & 10 & 1.8 & 13 & 7.3\end{array}$

Cleanliness of beds, covers, and linens

$\begin{array}{lrrrr}\text { Clean } & 537 & 97.0 & 543 & 48.0 \\ \text { Not clean } & 17 & 3.0 & 11 & 2.0\end{array}$

Explanation of treatment by doctor

$\begin{array}{lllll}\text { Yes } & 546 & 98.6 & 544 & 33.2\end{array}$

$\begin{array}{lllll}\text { No } & 8 & 1.4 & 10 & 1.8\end{array}$

Availability of laboratory

investigations when requested*

$\begin{array}{lllll}\text { Available at primary } & 398 & 71.8 & 435 & 78.5\end{array}$

health care facility

$\begin{array}{lllll}\text { Not available } & 156 & 28.2 & 119 & 21.5\end{array}$

*Significant at $\mathrm{P}<0.05 ;{ }^{*}$ Significant at $\mathrm{P}<0.01$; ***Significant at $\mathrm{P}<0.001$.

properly by doctors $(P>0.05)$ and $97.0 \%$ and $98.0 \%$ in Belbis and Abu Korkas respectively said they were satisfied with the cleantiness of the bedlinen $(P>0.05)$. In both districts, more than $98 \%$ of respon- dents were satisfied with the doctors' explanation of the treatment $(P>0.05)$.

Conversely, $28.2 \%$ of respondents in Belbis and $21.5 \%$ in Abu Korkas $(P<0.05)$ said that laboratory investigations recommended by the doctor were not available. As shown in Table 5, there was a highly significant difference between the two districts for satisfaction regarding the availability of prescribed drugs from the primary health care facility: $63.7 \%$ in Belbis compared with $84.1 \%$ in Abu Korkas. In addition, the satisfaction level regarding the amount of drugs prescribed was $52.2 \%$ in Belbis and $81.2 \%$ in Abu Korkas $(P<0.001)$.

Table 6 shows the average amount of the time spent in the facility. Mean time spent waiting for entry to the examination room was 22.2 minutes \pm 24.7 minutes with median value 15.0 minutes in Belbis, while in Abu Korkas, mean waiting time was 18.1 minutes \pm 23.3 minutes with

Table 5 Patient satisfaction regarding drug prescription

\begin{tabular}{lccccc}
\hline Variable & \multicolumn{2}{c}{$\begin{array}{c}\text { Belbis } \\
(n=554)\end{array}$} & \multicolumn{2}{c}{$\begin{array}{c}\text { Abu Korkas } \\
(n=554)\end{array}$} \\
& No. & $\%$ & No & $\%$ \\
\hline Drug prescribed available & & & \\
Yes & 353 & 63.7 & 466 & 84.1 \\
No & 201 & 36.3 & 88 & 15.9
\end{tabular}

Satisfaction with the quantity of the prescribed drugs ${ }^{\star \star \star}$

$\begin{array}{lllll}\text { Satisfied } & 289 & 52.2 & 450 & 81.2 \\ \text { Not satisfied } & 265 & 47.8 & 104 & 18.8\end{array}$

Overall satisfaction for the health care provided

\begin{tabular}{lrrrr} 
Satisfied & 541 & 97.7 & 541 & 97.7 \\
Not satisfied & 13 & 2.3 & 13 & 2.3 \\
\hline
\end{tabular}

***Significant at $\mathrm{P}<0.001$.

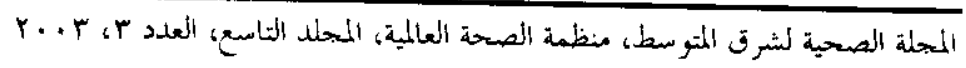


Table 6 Time spent seeking medical care, as perceived by patient (minutes)

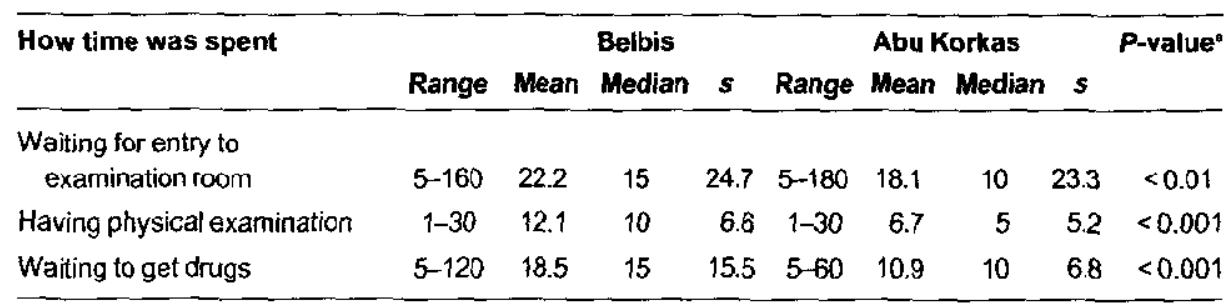

थsing Mann-Whitney $U$ test.

$\mathrm{s}=$ standard deviation

median value 10.0 minutes $(P<0.01)$. The duration of the physical examination ranged from 1 minute to 30 minutes with a mean of 12.1 minutes \pm 6.6 minutes in Belbis and a mean of 6.7 minutes \pm 5.2 minutes in Abu Korkas with the difference statistically significant $(P<0.001)$. The mean time spent actually obtaining the prescribed drug was 18.5 minutes \pm 15.5 minutes in Belbis (median 15 minutes) and 10.9 minutes \pm 6.8 minutes (median 10 minutes) in Abu Korkas district $(P<$ 0.001 ).

The overall satisfaction level with the health care provided was similar in both districts, at about $98 \%$

The results also revealed (not tabulated) that there was no significant relationship between patient satisfaction level and a respondent's age, sex, education level, type of service received or time needed to reach the primary health eare facility.

\section{Discussion}

This study assessed the overall patient satisfaction level for health care provided by primary health care facilities in two geographical areas, one in Upper and one in Lower Egypt. The sociodemographic characteristics of 1108 patients, 554 in each study area, revealed that the majority of those using primary health care facilities were middie-aged and female. A large majority of female patients had been expected from the start due to the fact that outpatient hours at the clinics were in the morning and early aftemoon, when most of the men at both sites were at work.

The illiteracy rate among both male and female respondents was noted as being significantly higher in Abu Korkas (Upper Egypt) than in Belbis (Lower Egypt). This was consistent with similar illiteracy rates reported in the most recent national census (1996).

Accessibility is one of the principles of health for all, as stated in Alma Ata declaration on primary health care (1978) [5]. Our results showed that the vast majority of respondents in both districts had convenient access to primary health care. Moreover, about $58 \%$ of patients in $\mathrm{Abu}$ Korkas and about $41 \%$ in Belbis said they could reach their primary health care units/ centres within 10 minutes. Similar results were obtained in Trinidad and Tobago regarding accessibility of primary health care facilities [0]. In a Saudi Arabian study, $13 \%$ of patients were dissatisfied with the accessibility to health care centres [7].

In terms of costs, primary health care in Egypt is relatively inexpensive as all preventive services are provided free of

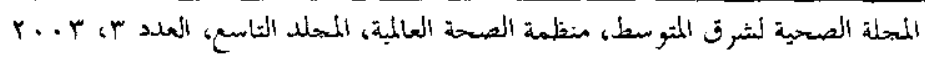


charge and the unit cost of a visit to outpatient facilities affiliated with the Ministry of Health and Population is 12.38 Egyptian pounds (1 Egyptian pound = US\$ 0.22). The patient's contribution is 6.69 Egyptian pounds, which includes the ticket price and cost of examination, investigations and drugs $\{8\}$. The vast majority of respondents $(95 \%)$ described the cost of a ticket (1 Egyptian pound) as reasonable.

In general, the results showed that the majority of patients are satisfied with the conditions of the waiting areas in primary health care units/centres. The waiting areas received satisfactory rankings with regard to size, comfort level and ventilation, Table 3.

A survey of different texts analysing patient-doctor/nurse relations revealed a consensus on a number of factors which determine patient satisfaction. They include proper acknowledgement of patients immediately upon arrival, allowing patients time to fully explain their health problems, a thorough examination with complete privacy followed by a thorough explanation by the doctor. Physicians should be encouraged to be punctual and attentive to the appointment schedule, so as not to cause too long a wait among patients [9-12].

The physical environment of outpatient clinics is an important factor in client satisfaction. Proper amenities enhance patient satisfaction level and willingness to return to the facility for subsequent health care needs $[13,14]$.

The satisfaction level among patients hinges on such factors as a relaxing physical environment and the attentiveness and "bedside manner" of the physician. These elements improve patient satisfaction and secure their intention to continue using health facilities. Regarding patient-doctor relations, especially during clinical examinations or consultations, $97 \%$ of general practitioners were described as patient and attentive. About $98 \%$ of patients surveyed said they were satisfied with the gencral practitioner's clinical examination, the physician's explanation of the prescribed treatment and the cleanliness of the beds. Our study also showed that about $97 \%$ of respondents were satisfied with nurse performance.

Nevertheless, one of the most consistent patient complaints was the presence of other patients inside the examination room at the time of examination, as mentioned by $16.2 \%$ and $50.7 \%$ of patients in Belbis and Abu Korkas respectively

Another point of dissatisfaction among the respondents was the inadequacy of the unit or centre's laboratory capabilities. Often, the tests and analysis ordered by the examining physician were unavailable at the primary health care facilities.

The issue of availability also arose regarding prescribed drugs: $26 \%$ of respondents reported that the prescribed drugs were not available from government facilities, forcing them to buy from more expensive private pharmacies. The issue of drug availability is a serious one. Until recently, there was no essential drug list available at the primary health care level in Egypt, but the Ministry of Health and Population has now issued essential drug lists for all levels of health care including the primary health vare level.

In addition, one-third of study patients expressed dissatisfaction with the amount of drugs prescribed to them. This complaint was voiced more frequently by patients in Belbis.

The few existing studies on waiting times and patient satisfaction in primary health care have shown mixed results- the extent of the relationship between waiting time and patient satisfaction is unclear. Many patients may overestimate the length

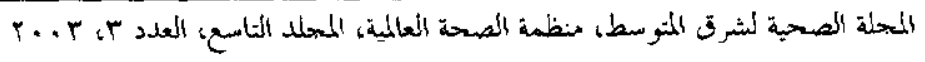


of their wait. Therefore, actual waiting time should be measured and compared with perceived waiting time and if the results do not differ significantly, that means the patients evaluated their waiting time fairly [14]. But in general, it can be stated that the longer customers wait for their health care, the less satisfied they will be, and therefore the less likely to return for further treatment $[15,16]$.

The overall satisfaction of the patients regarding the health care services provided at primary health care level was about $98 \%$ in both study sites. Another study in Egypt also reported a satisfaction rate of $95.9 \%$ for patients attending the outpatient clinics of university hospitals [/7]. However, Sayed et al. reported an overall satisfaction rate of $90.5 \%$ among patients attending rural health units in Egypt [/8].

These figures both compare tavourably with similar patient satisfaction studies conducted in other countries. In Germany, the overall satisfaction rate among patients asked to evaluate their general practitioner was $95.4 \%$ [9]. Lower satisfaction rates were reported in Saudi Arabia, where the rate was only $60 \%$, due in large part to language barriers, the relative inaccessibility of health facilities and the absence of specialty clinics [7]. A very low rate of satisfaction $(35.1 \%)$ was also reported in Bosnia and Herzegovina due to inaccessibility of health care, facility cleanliness and frequent staff turnover [19].

The high rate of overall satisfaction in the present study may reflect the recent improvements in the district health care system through a three-year upgrading project undertaken in both sites. This project was a collaborative effort between the Ministry of Health and Population and the Social Fund of Egypt, and includes facility renovation, equipment upgrading and staff development activities. It may also be due to the easy accessibility of health care facilities in Egypt. Supporting this explanation, Mcng et al. 1997, reported that accessibility is the strongest predictor of overals satisfaction with quality of health care $[20]$.

The primary negative aspects revealed by the study include the lack of privacy during clinical consultations and what appears to be a chronic shortage of both prescribed drugs and laboratory analysis facilities. These issues must be addressed by health authorities at both the district and national levels in order to improve the overall quality of Egyptian health care.

\section{References}

1. Dansky KH, Miles J. Patient satisfaction with ambulatory health care services: waiting time and filling time. Hospital \& health services administration, 1997, 42(2):165-77.

2. Wartman SA. Patient understanding and satisfaction predictors of compliance. Medical care review, 1983, 21(9):88691.
3. Strasser S, Davis RM. Measuring patient satisfaction for improved patient service. Ann Arbor, Michigan, Health Administration Press, 1991.

4. Gann MJ, Restuccia JD. Total quality management in health care: a view of current and potential research. Medical care review, 1994, 51(4):467-500.

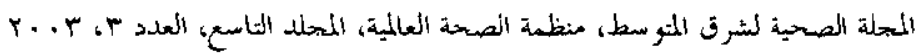


5. Primary health care: report of the international Conference on Primary Health Care, Alma-Ata, USSR, 6-12 September 1978 jointly sponsored by the Word Health Organization and the United $\mathrm{Na}$ tions Children's Fund. Geneva, World Health Organization, 1978.

6. Singh H, Haqq ED, Mustapha N. Patients' perception and satisfaction with health care professionals at primary health care facilities in Trinidad and Tobago. Bulletin of the World Health Organization, 1999, 77(4):356-60.

7. Ali M, Mahmoud ME. A study of patient satisfaction with primary health care services in Saudi Arabia. Journal of community health, 1993, 18(1):49-54.

8. Health Sector Reform Programme (HSRP). Health care financing: overview and situational analysis. Cairo, Ministry of Health and Population. 1997:93-104.

9. Imanaka $Y$ ef al. [Determinants of patient satisfaction and intention to continue service utilization: analysis of a survey of outpatients at general hospital]. Nippon koshu eisei zasshi [Japanese journal of public health], 1993, 40(8):624-5 [in Japanese].

10. Klingenberg A, Bahrs $O$, Szecsenyi J. Wie beurteilen Patienten Hausarzte und ihre Praxen? Deutsche Ergebnisse der europ ischen Studie zur Bewertung hausarztlicher Versorgung durch $\mathrm{Pa}$ tienten. [How do patients evaluate general practice? German results from the European Project on Patient Evaluation of General Practice Care (EUROPEP)]. Zeitschrift für rztliche Fortbildung und Qualitatssicherung, 1999, 93(6):43745.

11. Gomez MJ et al. Satisfacci n de los usuarios de una zona de salud. Diferencias seg $n$ modelo asistencial. [User satisfaction in a health district. Differences according to the care model]. Atenci n primaria, 1997, 20(2):90-3.
12. Lim $\mathrm{HC}$ et al. Why do patients complain? A primary health care study. Singapore medical journal, 1998, 39 (9):390-5.

13. Øvretveit J. Health service quality. London, Blackwell Scientific Publications, 1992.

14. Brown LD et al. Quality assurance of health care in developing countries. Bethesda, Maryland, The Quality Assurance Project, Centre for Human Services, 1993.

15. Clemmer EC, Schneider B. Managing customer dissatisfaction with waiting. Applying social-psychological theory in a service setting. Advances in service marketing and management, 1993, (20): 213-29.

16. Katz K, Larson BM, Larson RC. Prescription for waiting in line blues: entertain, enlighten, and engage. Sloan managoment review, 1991, 32(2):44-53.

17. El-Awady MY. Satisfaction of clients attending outpatient clinics at Ain Shams University Hospital. Journal of the Egyptian Public Health Association, 1999, 74(3):4.

18. Sayed HA, El Ayyat A, Abd El Hady A. Patient satisfaction as a measure of medical care in some government-operated health facilities. Egyptian journal of community medicine, 1999, 17(2).

19. Masic I. Evaluacija zadovoljstva gradana $s$ organizacijom sistema primarne zdravstvene zastite. [Evaluation of citizen satisfaction with the organization of the primary health care system]. Medicinski arhiv, 1991, 45(3-4):123-5

20. Meng $Y Y$ et al. Satisfaction with access to and quality of health care among Medicare enrollees in a health maintenance organization. Western journal of medicine. 1997, 166(4):242-7.

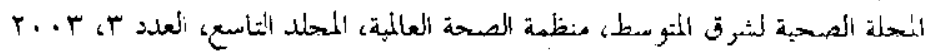

